\title{
First record of Anaphothrips ponokikirmui Kudo, 1989 (Thysanoptera: Thripidae) from Russia
}

\section{Первая находка трипса Anaphothrips ponokikirmui Kudo, 1989 (Thysanoptera: Thripidae) на территории России}

\author{
T.G. Evdokarova ${ }^{1}$, G. Vierbergen ${ }^{2}$ \\ Т.Г. Евдокарова ${ }^{1}$, Г. Виерберген ${ }^{2}$
}

\footnotetext{
${ }^{1}$ Institute for Biological Problems of Cryolithozone SB RAS, Lenin Avenue 41, Yakutsk 677980, Russia. E-mail: evdokarova@mail.ru

${ }^{2}$ Netherlands Food and Consumer Product Safety Authority, Laboratory of Entomology, P. O. Box 9102, 6700 HC, Wageningen, Netherlands. E-mail: g.vierbergen@nvwa.nl

${ }^{1}$ Институт биологических проблем криолитозоны СО РАН, пр. Ленина, 41, Якутск 677980, Россия.
}

KEY WORDS: thrips, fauna, Anaphothrips ponokikirmui, Calamagrostis, new synonym КЛЮЧЕВЫЕ СЛОВА: трипсы, фауна, Anaphothrips ponokikirmui, Calamagrostis, новый синоним.

ABSTRACT: Anaphothrips ponokikirmui Kudo, 1989 is for the first time recorded from Russia. Morphological description of this grass-living species from its close allies are provided. A. oroqeni Cui et Wang, 2019 is synonymized with $A$. ponokikirmui.

PЕЗЮМЕ: Anaphothrips ponokikirmui Kudo, 1989 впервые обнаружен в фауне России. Приводятся морфологические признаки этого вида. A. oroqeni Cui et Wang, 2019 переведён в синоним A.ponokikirmui.

Of the genus Anaphothrips 86 species are described in the world fauna [ThripsWiki, 2020]. Four species of this genus are known in Russia: Anaphothrips obscurus (Müller, 1776), A. badius (Williams, 1913), A. euphorbiae Uzel, 1895, A. gracillimus Priesner, 1923 [Meshcheryakov, 1986; Schliephake, 1977; Vierbergen G., 2019]. From the fauna of Yakutia are known A.obscurus and $A$. badius [Bagachanova, 2001; Evdokarova \& Doricova, 2013]. Recently, comprehensive investigations in the province resulted in at least two new Anaphothrips species of this region. One of these is reported here.

\section{Material and methods}

Thrips were collected in Central Yakutia. Specimens were macerated with $\mathrm{KOH}$ and enclosed in Canada Balsam. All measurements and descriptions were made with an Olympus BX51 microscope at 40x, 100x, 200x, 400x and 1000x magnification, with phase contrast option. All measurements are in micrometers $(\mu \mathrm{m})$. Photos were taken with a Leica DFC450 C camera and Imagic IMS Client software.

\author{
Order THYSANOPTERA \\ Suborder TEREBRANTIA \\ Family THRIPIDAE \\ genus Anaphothrips Uzel, 1895
}

Anaphothrips ponokikirmui Kudo, 1989

Figs 1-8.

MATERIAL. Russia: Central Yakutia, environs of Yakutsk, Vilyui tract $13 \mathrm{~km}, 62^{\circ} 02^{\prime} \mathrm{N}, 129^{\circ} 28^{\prime} \mathrm{E}$, Calamagrostis 21.07 .2017 7 우 (4 hemimacroptera, 3 microptera), $40^{7}$ (2 hemimacroptera, 2 microptera); leg. Evdokarova T.G. Material is added to the collection of IBPC SB RAS $\left(5+, 20^{7}\right)$, Senckenberg Museum Frankfurt am Main, Germany $\left(1+10^{7}\right)$ and to National Reference Centre, Wageningen, the Netherlands $\left(1\right.$,, $\left.10^{7}\right)$.

DISTRIBUTION. Russia: E Siberia: C Yakutia; China: Heilongjiang; Japan: Hokkaido and Honshu.

DESCRIPTIONS (measurements in micrometers)

Female (micropterous) completely yellow (Fig. 1), with tip of rostrum and tip of abdominal X brown; body length 1370; head length 142 , width 166 ; with transversely striae on posterior half; outside ocellar triangle; antennae 9-segmented (Fig. 2), length antennae 268; IV and V yellow, but darkening to the apex and VI-IX brown, segments III-IV with forked sensorium; III-VI with rows of microtrichia; VI with an incomplete oblique suture; all body setae yellow; pronotum without long setae (Fig. 3); pronotum length 130, width 186; with faint transversely striae on anterior and posterior parts; mesonotum with transversely striae, with 2 medial setae; metanotum reticulate sculpture, with medial setae on anterior third, without campaniform sensillae (Fig. 4); metascutellum some longitudinal striae, with some tergite III-VII medially with very faint sculpture, tergite II-VII with lateral serrations at posterior margin (Fig. 5); tergite VIII with complete comb with about 20 long hairs, tergite IX with S1 about 102 (Fig. 6); Wings are developed or short, grayish brown (Fig. 7).

Male: yellow, micropterous with small round to oval pore plates on sternite III-VII (Fig. 8).

How to cite this article: Evdokarova T.G., Vierbergen G. 2021. First record of Anaphothrips ponokikirmui Kudo, 1989 (Thysanoptera: Thripidae) from Russia // Russian Entomol. J. Vol.30. No.2. P.146-148. doi: 10.15298/rusentj.30.2.06 

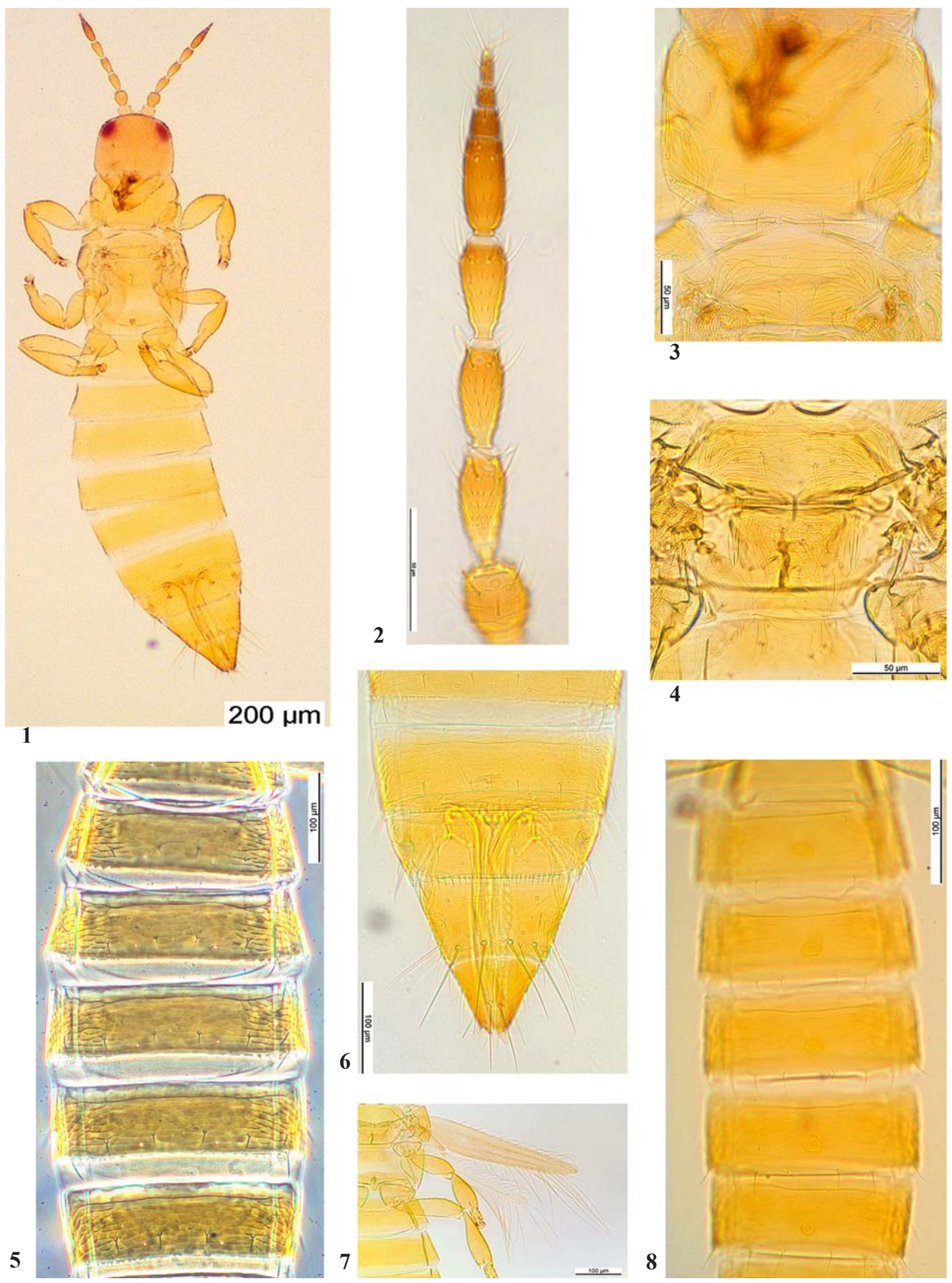

Figs 1-8. Anaphothrips ponokikirmui: 1 - habitus; 2 - antennae; 3 - pro- and mesonotum; 4 - metanotum; 5 - tergites III-VII (phase contrast); 6 - tergites VIII-IX; 7 - wing; 8 - sternites III-VII; 1 -7 - female; 8 - male.

Pис. 1-8. Anaphothrips ponokikirmui: 1 - внешний вид; 2 - усики, 3 - про- и мезонотум; 4 - метанотум; 5 - III-VII тергиты (фазовый контраст); 6 - VIII-IX тергиты; 7- крыло; 8 - III-VII стерниты; 1 -7 - самка; 8 - самец. 
REMARKS. A. ponokikirmui is similar to A. obscurus, but differs in the metanotum without campaniform sensillae and body completely yellow.

The Yakutian specimens differ in position of mesonotal median pair of setae and metanotal median setae. Kudo [1989] gives in the original description for the female "interdistance of inner (anterior) pair more than 0.8 times as long as interdistance of outher (posterior) pair". In Yakutian specimens this ratio is 0.53 to 0.65 . This position is not stable in these specimens (Figs 3-4) and therefore a variable character. We synonymize Anaphothrips oroqeni Cui et Wang, 2019 with $A$. ponokikirmui because the differences given under 'remarks' of the description of $A$. oroqeni by Cui and Wang [2019] are not valid. The authors state tergite $\mathrm{X}$ should be yellowish in $A$. oroqeni and, in contrast, this segment should be brown in A. ponokikirmui. Kudo [1989], however, they describe colouration of segment $\mathrm{X}$ as yellow, with the tip of the segment brown. The latter can be seen clearly in fig. 45 in Cui \& Wang [2019]. The second differential character given by Cui and Wang is the lack of serrations in the medial part of tergite II to VII of $A$. ponokikirmui. In figure 4 of Kudo [1989] laterally pointed lobes are seen, which he describes as "distinct serrations". Absence of medial weakly developed serrations (indistinct serrations) is not mentioned by him. These laterally pointed lobes are seen in figure 39 in Cui and Wang as well as medially weakly developed serrations. In Yakutian material posteromedially tergites V to VII have indistinct serrations; they are most strong in the VII and are absent in tergite IIIV (Fig. 1). Between specimens development of these medial serrations is as a rule variable and in this case this character of presence/absence is not valid for species separation.

KeY tO THE SPECIES OF THE GENUS ANAPHOTHRIPS OF THE FAUNA YAKUTIA

1. Body and antennae brown, antennal segments III-IV paler. Both sexes fully winged. Abdominal tergites without sculpture lines ........................ A. badius (Williams)

- Body yellow. Abdominal tergites with transverse lines. Macro- and brachypterous

2. Body yellow or light brown, with brown spots. Metanotum with a pair of campaniform sensillae. Tergites II-VII without lateral serrations at posterior margin
- Body completely yellow without brown spots. Metanotum without campaniform sensillae. Tergites II-VII with lateral serrations at posterior margin. Male on III-VII sternites with small round to oval pores .... A. ponokikirmui Kudo

Acknowledgments. The authors are grateful to N.N. Vinokurov (Institute for Biological Problems of Cryolithozone SB RAS, Yakutsk) for varuable advice during the work on the paper and to V.I. Rozhina (Kaliningrad) for her help in identification of the species. The research was carried out within the state assignment of Ministry of Science and Higher Education of the Russian Federation (theme No. 0297-20210044, reg. No.121020500194-9).

Competing interests. The authors declare no competing interests.

\section{References}

Bagachanova A.K. 2001. [Experience studying insects and mites in perennial grass stands at the Nyurba Research and Production Station of ING AS RS (YA)] // Teoreticheskie i prikladnye voprosy travoseyaniya $\mathrm{v}$ kriolitozine. Yakutsk. No.1. P.140155 [in Russian]

Evdokarova T.G., Doricova M. 2013. [New records of the Thrips (Insecta, Thysanoptera) in Central Yakutia] // Amurskiy zoologicheskiy zhurnal. T.5. No1. P.21-22 [in Russian].

Meshcheryakov A..A. 1986. [Order Thysanoptera] // Opredelitel' nasekomykh Dal'nego Vostoka SSSR. T.1. Leningrad: Nauka. P.380-431 [in Russian].

Cui Y., Wang J. 2019. The genus Anaphothrips (Thysanoptera, Thripidae) in China, with three new species // Zootaxa. Vol.4700. No.2. P.246-258.

Kudo I. 1989. The Japanese species of Anaphothrips and Apterothrips (Thysanoptera,Thripidae) // Japanese Journal of Entomology Vol.57. No.3. P.477-495.

Schliephake G. 1977. Ein Beitrag zum Vorkommen der Thysanopteren im Kursker Gebiet (Sowjetunion) // Wiss. Hefte d. Päd. Hochschule "W. Ratke" Köthen. Vol.4. No.12. P.124-131.

Strassen R. 2003. Die Terebranten Thysanopteren Europas und des Mittelmeer-Gebietes // Die Tierwelt Deutschlands. Bd.74. Keltern: Goecke \& Evers. 277 S.

ThripsWiki. 2020. ThripsWiki — providing information on the World's thrips. http://thrips.info/wiki/Anaphothrips [accessed 15.12.2020]

Vierbergen G. 2020. Thysanoptera. Fauna Europaea version 2017. https://fauna-eu.org (accessed 15.12.2020). 